\title{
The Technology Ownership and Information Acquisition Habits of HBCU Freshmen
}

\author{
Nicole A. Buzzetto-More \\ University of Maryland Eastern \\ Shore, Princess Anne, \\ MD, USA
}

Nabuzzetto-more@umes.edu

\author{
Retta Sweat-Guy \\ Fayetteville State University, \\ Fayetteville, \\ NC, USA
}

rguy@uncfsu.edu

\begin{abstract}
In a world of expanding information and technological resources, there is increasingly a need for a citizenry that is able to access and use information and technology effectively (American Library Association, 2000). An information and technologically literate person should have access to, and be able to use, a host of available resources that include libraries, databases, and the internet in order to retrieve, evaluate, and use information effectively (Weil, 2006). This paper reports the findings of a study conducted at two Historically Black Universities that examined technology ownership and usage, as well as, the information acquisition habits of freshmen.
\end{abstract}

Keywords: Technological Literacy, Information Literacy, Technology Ownership by Minority Students, HBCU Freshmen

\section{Introduction}

Information literacy is the ability to collect, evaluate, assemble, reflect upon, and use information in order to learn and inform problem-solving and decision making (Bruce, 2003). Technological literacy which is increasingly being tied into information literacy is the understanding of the uses, functions, and purposes of technology for the achievement of goals (Pearson \& Young, 2002). Both are skills that are increasingly playing an important role in lifelong learning and that are dependent on the ability to engage in critical and reflective thinking (Bruce, 2003).

Founded in 1886, the University of Maryland Eastern Shore (UMES) is a historically black, 1890 land grant institution and a member of the University System of the State of Maryland. The student body is approximately 3,762, reporting a student population that is approximately $74 \%$ African-American and $26 \%$ White and other. Almost $11 \%$ of the student population is international students that primarily come from the continent of Africa and/or from the Caribbean region. The majority of incoming freshmen have an SAT score of under 1,000 , the retention rate is $69.7 \%$ and

Material published as part of this publication, either on-line or in print, is copyrighted by the Informing Science Institute. Permission to make digital or paper copy of part or all of these works for personal or classroom use is granted without fee provided that the copies are not made or distributed for profit or commercial advantage AND that copies 1) bear this notice in full and 2) give the full citation on the first page. It is permissible to abstract these works so long as credit is given. To copy in all other cases or to republish or to post on a server or to redistribute to lists requires specific permission and payment of a fee. Contact Publisher@InformingScience.org to request redistribution permission. the graduation rate is $52.6 \%$. All incoming freshmen are required to take a freshmen experience course offered by their respective departments known as professional development. This survey was administered to students at UMES in the fall of 2005 enrolled in Freshmen Professional Development (BUED 101) designed for freshmen business majors. The Department of Business Management and Accounting is one of the larg- 
est departments on campus with over 420 majors, offering programs that include Business Management, Marketing, Accounting, and Business Education.

Fayetteville State University (FSU) is a historical Black institution located in Fayetteville, North Carolina, and that is part of the University System of North Carolina. It is the second-oldest public institution of higher education in the state, founded in 1867. It serves a student population of approximately 5,300 with a student body that is $73 \%$ Black, $18 \%$ White, and $4 \%$ Hispanic. The majority of incoming freshmen have an SAT score of under 1,000 and the faculty-to-student ratio of 1-to-20. FSU offers a Freshman Year Initiative designed to assist freshmen in the transition from high school to university life. All incoming students are required to enroll in the program before they can be admitted to a degree program. The FSU component of this study involved the use of the same survey instrument that was employed at UMES and was administered in the fall of 2005 during the week of September 26, 2005 to all freshmen students.

The populations studied at both institutions were freshmen students enrolled in their institutions respective freshmen experiences courses. Whereas the UMES the students surveyed were exclusively business majors, at FSU a larger population was examined representing multiple discipline areas. The instrument utilized was identical at both institutions and contained a mixture of LikertScale, multiple-choice, and yes/no questions (see Appendix).

\section{Literature Review}

There are a number of popular definitions of information literacy. According to Caroline Stern (2002) information literacy is the critical location, evaluation and use of information. Bruce (2003) defines information literacy as the ability to gather, critique, pull together, reflect upon, and use information effectively. Bruce explains that information literacy is a skill crucial to lifelong learning that is dependent on the ability to engage in critical and reflective thinking and notes that information literacy suggests learning outcomes and the ability to relate knowledge and experiences to real life practice by stressing the making of connections.

Information literacy involves teaching a process that transforms the very understanding of learning (Breivik, 2000) and is a skill necessary for both lifelong and self-directed learning (American Library Association, 2000).

Information literacy is becoming increasingly more important in our world that is rapidly evolving through the growth and proliferation of technological and information resources (American Library Association, 2000). As a result, individuals are faced with countless information choices and must decide which resource(s) to use in the acquisition of information (libraries, community resources, journals and databases, special interest organizations, news and popular media, and the World Wide Web) and determine the authenticity, validity, and usability of the information they discover (American Library Association, 2000).

Information literacy relates to the type of school reform discussed by Linda Darling Hammond who explains that in order for a person to be educated they must be able to seek out information, analyze, create, and use one's own intelligences (1994). Technology skills are an integral part of the information literacy equation requiring individuals to be able to use software applications, databases, online libraries, the World Wide Web, and a host of other technologies in order to achieve a wide range of academic, professional, and personal goals (American Library Association, 2000). An information and technologically literate person should be able to use a host of available technologies to recognize the need for information, to retrieve the necessary information, and to use that information effectively (Weil, 2006). 
In their publication entitled, Technically speaking: Why all Americans need to know more about technology (Pearson \& Young, 2002) the National Academy of Engineering and the National Research Council provide the following rationale in support of technological literacy:

Technological literacy encompasses three interdependent dimensionsknowledge, ways of thinking and acting, and capabilities. Like literacy in science, mathematics, social studies, or language arts, the goal of technological literacy is to provide people with the tools to participate intelligently and thoughtfully in the world around them (p. 3).

The article further asserts that "technological literacy is more of a capacity to understand the broader technological world rather than an ability to work with specific pieces of it" (Pearson \& Young, 2002, p. 22).

The North Central Regional Educational Laboratory (2006) defined technological literacy as the knowledge of technology its uses, functions, operations, the purposes it can serve, and how it can be used efficiently and effectively to achieve specific goals. It includes knowledge, ways of thinking and acting, and the skills and abilities for effective and efficient use (Pearson \& Young, 2002 pp. 4)

The No Child Left Behind Act addressed technological literacy by requiring our nation's schools to strive for technological literacy for all students by the eighth grade (No Child Left Behind Act of 2001, Part D, Sec. 2402). The International Society for Technology in Education (ISTE) (2000) developed the National Education Technology Standards (NETS) which has offered a definition of technological literacy that has been widely accepted by K-12 schools. In higher education standards for information literacy were established by the Association of Colleges and Research Libraries (American Library Association, 2000).

A 2003 report published by the International Technology Education Association entitled Advancing Excellence in Technological Literacy: Student Assessment, Professional Development, and Program Standards describes technology literate people as having the ability to solve problems and to objectively examine technological issues from different points of view. The publication (International Technology Education Association, 2003) also states that technologically literate persons have the ability to utilize concepts from other content areas as tools for understanding and managing technological systems.

From an educational standpoint, the North Central Regional Educational Laboratory (2006) recently introduced a description of a technologically literate student as one who: can demonstrate an understanding of the concepts of technological systems; is a proficient technology user; uses a variety of technologies to increase productivity; uses technology effectively to communicate; uses technology to access, evaluate, process and synthesize information from a multitude of sources; and uses technology for complex problem solving.

A study conducted by the National Academy of Engineering (Pearson \& Young, 2002) showed that most American adults and children are technologically illiterate and that the American educational system has not made significant strides at recognizing the importance of technological literacy. Pearson \& Young (2002, pp. 104-105) explain that while most schools acknowledge the importance of technology to their students' futures, few have successfully incorporated technology throughout the learning process.

Instructional technologists recognize the importance of learning to search. According to Brem and Boyes (2001), the mechanics of online searching are exercises in critical thinking that can improve cognitive development as well as our use of online resources. They explain that a search can encourage the application of metacognition, hypothesis testing, and argumentation and 
Buzzetto-More (2006) further explained that the ability to search, select, and evaluate are part of the definition of information literacy.

The digital divide remains a significant concern in the United States, with race/ ethnicity, income level, and education contributing to inequalities with use of computers and reliable and expedient access to the internet (Morgan \& VanLegen, 2005). According to Jackson, Ervin, Gardner, \& Schmitt (2001) the ways that students of different groups benefit from technology facilitated instruction is also divided with minority students from lower socio-economic backgrounds more likely to have experienced drill and practice, while white students from higher socio-economic backgrounds more likely to benefit from technologies that help build, and require the use of, higher order thinking skills.

Minorities have been found to be less likely to be technological literate; for example, when using the internet African Americans and Hispanics have been shown to be less likely to search for news, and/or conduct informational searches (United States Department of Commerce, 2002). Sax, Ceja, and Teranishi (2001) conducted a nationwide survey of college freshmen and found that level of technological preparedness varied significantly by race, class, and academic background. They also found that racial differences with technology also persisted despite such key variables as parents' level of education and income as well as high-school type and concluded that the technological disparities are a hindrance to students' academic success. A more recent study conducted by Buzzetto-More and Sweat-Guy (2006) found marginal correlations between parents' level of education and technological ownership and readiness.

Libraries have transformed from brick and mortar institutions that were repositories for printed works to technology enabled multi-media linkage and distribution resources that are accessible both via physical buildings as well as digitally. According to Smith (1999) it is a myth that library usage is on the decline due to competition from electronic sources; however, Hull (2005) found that students from low socioeconomic backgrounds are less comfortable in, and less proficient at using and navigating university libraries. Hull explains that the lack of a literary or library tradition in the home can lead to feelings of alienation in a large academic library setting.

Historically Black Colleges and Universities (HBCUs) were established for the explicit purpose of educating African Americans at a time when they were the only postsecondary option for most blacks. Overtime HBCUs they have become well adept at promoting the college success of African Americans offering an environment that encourage student engagement, retention, and success (Laird, Bridges, Homes, Morelon, \& Williams 2004). Studies have shown that attending an HBCU contributes positively to student outcomes (Flowers, 2002; Outcalt and Skewes-Cox, 2002). At the same time, Black students who attend HBCUs have been found to be from lower socio economic backgrounds and be less prepared for college than Black students attending traditional majority institutions (Allen, 1987).

\section{Methodology}

A survey was administered at two HBCUs, Fayettville State University located in Fayetville, South Carolina and the University of Maryland Eastern Shore located in Princess Anne, Maryland. The two institutions are comparable in size and serve similar student populations. The population studied at both universities were freshmen students enrolled in their institutions respective freshmen experiences courses. Whereas the students surveyed at UMES were exclusively business majors, at FSU a larger population was a examined that were representative of all discipline areas. The instrument utilized was identical at both institutions and contained a mixture of LikertScale, multiple-choice, and yes/no questions (see appendix). SPSS was utilized during the data analysis process. Likert-Scale questions were evaluated based on mean, mode, minimum and maximum responses, standard deviation, and percentages. Multiple-choice and yes/no responses 
were evaluated on a percentage basis. Additionally, cross-tabulations, Chi-Square tests, and ANOVAs were run with respect to several questions in order to determine relationships.

The survey included a range of questions that looked at students' technology ownership and access, internet use, methods for seeking information and conducting research, library usage, and experiences with online databases and digital libraries and had a response rate at both institutions that exceeded $90 \%$. Although the survey did not directly and explicitly measure all of the specific skills that mark the standards for determining information and technological literacy, it did examine and provide a meaningful snapshot of the technology usage and ownership as well as the information acquisition habits and preferences of the participating students, information that will prove useful in building and addressing the information and technology literacy needs of minority students.

\section{Findings}

The study had a total population of 748 participants, 646 from Fayetteville State University and 102 from the University of Maryland Eastern Shore. Of which, 81\% (606) were African American, 5.7\% (43) White, 3.7\% (28) Hispanic, 3.5\% (26) African, 2.9\% (22) other, 1.1\% (8) Asian, $.9 \%$ (7) Caribbean Islander, and .5\% (4) Pacific Islander. The majority of the participants were first-time freshmen $(93.5 \%)$ with less than $7 \%$ reporting that they were transferring freshmen. The majority of the students were between the ages of $17-19$ (87\%); with $5.9 \% 20-21 ; 2.4 \% 22-$ 23 ; and $3.3 \% 31$ and older. In terms of gender, $33.7 \%$ of the participants reported that they were male and $66.3 \%$ female.

The participants were asked about their computer ownership and $74 \%$ reported that they currently owned a computer, with $83 \%$ having had a computer at home during high school, and $65 \%$ having had a computer at home during middle school. These numbers are significantly higher than those reported by the major research studies such as the one conducted by the National Center for Education Statistics (2003) that stated that only $41 \%$ of blacks and Hispanics own a home computer. Additionally, when asked to rank themselves as computer users, most of the participants rated themselves as intermediate computer users (74\%), with $18 \%$ rating themselves as a novice and only $8 \%$ as an expert.

Home internet access was fairly prevalent with $86 \%$ responding that they have internet access at home which indicates significant growth from the $39.8 \%$ reported by the National Center for Education Statistics in 2002. The primary location for accessing the internet was similar to what has been reported in the literature with $58.9 \%$ said they are most likely to access the Internet at school, compared to $1.5 \%$ who seek access at work, and $38.3 \%$ who primarily obtain access at home.

The students go online frequently with $83 \%$ reporting daily. Approximately $19.3 \%$ spend $1-2$ hrs/weekly; 32\% spend 3-5 hours online per week; $19 \%$ spend $6-8 \mathrm{hrs} /$ weekly; $11 \%$ spend $9-11$ hrs/weekly; $4.4 \%$ spend $12-15$ hrs/weekly; $7.4 \%$ spend $16-21 \mathrm{hrs} /$ weekly; and $6 \%$ spend 22 or more hours per week online. The most frequent online activity was reported as: email (38\%); school work (23\%); instant messaging (14\%); surfing (11\%). This data was similar to what was reported in a 2005 EduCause study (Caruso \& Kvavik, 2005). On the other hand, a number of activities that Educause found to be common among college students were less common among the participants in this study such as online shopping (4.3\%), music downloading (3.9\%), blogging $(0.9 \%)$, and gaming $(3.5 \%)$.

Students were asked about their college preparation, application, and selection process. According to the participating students: $21 \%$ participated in a pre-college program; $18 \%$ applied to 1 college; $49 \%$ applied to $2-3$ colleges; $25 \%$ applied to $4-5$ colleges; $5.8 \%$ applied to $6-7$ colleges; and less than $2 \%$ applied to 8 or more colleges. Sixty percent responded that they submitted their col- 
lege applications online with $42 \%$ saying that they conducted their college search at college fairs; $24 \%$ noting that they utilized the assistance of their guidance counselors' office to assist them in their college search; $21 \%$ conducted their college search online; and 13\% relied on other means. Thirty nine percent of students said that the primary reason that they selected either UMES or FSU was because of the institutions status as a Historically Black College or University (HBCU) with $29 \%$ responding that $\mathrm{HBCU}$ status did not play a role in their college decision.

In contrast to studies conducted by Jackson, Ervin, Gardner, \& Schmitt (2001) the participants reported being involved in a variety of project based learning activities that were facilitated by computers. Approximately, $74 \%$ have used a computer to solve a problem as part of a class assignment, $86 \%$ have participated in group work that involved using computer software for school, and $82 \%$ have created and/or delivered a presentation using computer software while in school. On the other hand, only 33\% reported that they have done a computer simulation in school.

When asked to respond to the statements I regularly visit the library, I visit the library when I need to conduct research for papers and projects, and I am comfortable locating quality research materials in the library: $35 \%$ of students said that they regularly visit the library with $38 \%$ strongly disagreeing; $75 \%$ agreed that they visit the library when they need to conduct research, with $12 \%$ disagreeing and $12 \%$ expressing neutrality; and $60 \%$ said that they are comfortable locating quality materials in the library with $22 \%$ expressing neutrality and $16 \%$ expressing disagreement. These findings only marginally support the work of Hull (2005) who found that students from low socioeconomic backgrounds are less comfortable in, and less proficient at using and navigating university libraries.

Sixty-seven percent of the respondents said that they prefer to do research for papers and projects online with $21 \%$ expressing neutrality and $12 \%$ disagreeing. Seventy percent self reported that they know where to find quality academic research materials online with $21 \%$ responding neutral and $9 \%$ disagreeing. On the other hand, only 53\% search journals and research databases online and when conducting an online search $73 \%$ responded that they are most likely to Google or Ask. This echoed the findings of similar studies that have indicated that minorities are less likely to be technological literate and less likely to use the internet to search for news, and/or conduct informational searches (United States Department of Commerce, 2002).

The respondents indicated infrequent library usage that contradicted the earlier responses to the statement I regularly visit the library (35\% agreement) with $28 \%$ responding that they were frequent users (10\% daily and $18 \%$ often) compared with $39 \%$ who said they were infrequent library users $(17 \%$ never and $22 \%$ very little/seldom). In contrast, $78 \%$ of the respondents said they conduct frequent online searches (41\% daily and $37 \%$ often). This data supports the work of Hull (2005) who found that students from lower socioeconomic backgrounds to be less comfortable and proficient in the use of libraries. Conversely, these findings differed from those published by Smith in 1999 who said that it is a myth that library usage is on the decline due to competition from electronic sources.

Only $18 \%$ of the respondents said that they would rather do research in a library than online with $31 \%$ expressing neutrality and $50 \%$ disagreeing. This may serve to further affirm the findings of Hull (2002) who explains that the lack of a literary or library tradition in many African American homes can lead to feelings of alienation in academic libraries.

Interestingly, while sixty-one percent said they regularly use the computer labs on campus, only $54 \%$ responded that their career plans involve the use of computers.

The students' perceptions and experiences with online learning were similar to the findings reported by a 2005 Educause study (Caruso \& Kvavik, 2005) which found that students want to see 
traditional learning supported by e-learning strategies; however, face-to-face instruction is preferred over fully online learning.

The students were asked a number of Likert-Scale questions where $5=$ strongly agree; $4=$ agree; $3=$ neutral/undecided; $2=$ disagree; $1=$ strongly disagree; and NA=not applicable. The findings are expressed in Table 1.

Table 1: Responses to Likert Scale Questions

\begin{tabular}{|l|c|c|c|c|c|c|}
\hline & 5 & 4 & 3 & 2 & 1 & NA \\
& $\mathrm{SA}$ & $\mathrm{A}$ & $\mathrm{N}$ & $\mathrm{DA}$ & $\mathrm{SD}$ & \\
\hline $\begin{array}{l}\text { I chose FSU/UMES because it is a historically } \\
\text { Black university. }\end{array}$ & $14 \%$ & $25 \%$ & $27 \%$ & $14 \%$ & $15 \%$ & $5 \%$ \\
\hline $\begin{array}{l}\text { I plan on taking a fully online course that does not } \\
\text { meet in person in the future. }\end{array}$ & $9 \%$ & $10 \%$ & $24 \%$ & $16 \%$ & $35 \%$ & $5 \%$ \\
\hline I regularly visit the library. & $14 \%$ & $21 \%$ & $27 \%$ & $23 \%$ & $14 \%$ & $2 \%$ \\
\hline $\begin{array}{l}\text { I visit the library when I need to conduct research } \\
\text { for papers and projects. }\end{array}$ & $34 \%$ & $41 \%$ & $12 \%$ & $6 \%$ & $6 \%$ & $1 \%$ \\
\hline $\begin{array}{l}\text { I am comfortable locating quality research materials } \\
\text { such as books and journal articles in the library. }\end{array}$ & $24 \%$ & $36 \%$ & $22 \%$ & $12 \%$ & $4 \%$ & $1 \%$ \\
\hline $\begin{array}{l}\text { I prefer to do my research for my papers and pro- } \\
\text { jects online. }\end{array}$ & $37 \%$ & $30 \%$ & $21 \%$ & $7 \%$ & $5 \%$ & $.4 \%$ \\
\hline $\begin{array}{l}\text { I know where to find quality academic research ma- } \\
\text { terials online. }\end{array}$ & $33 \%$ & $37 \%$ & $21 \%$ & $6 \%$ & $3 \%$ & $.4 \%$ \\
\hline I search journals and research databases online. & $22 \%$ & $31 \%$ & $22 \%$ & $14 \%$ & $8 \%$ & $2 \%$ \\
\hline $\begin{array}{l}\text { When conducting an online search I am most likely } \\
\text { to Google or Ask Jeeves. }\end{array}$ & $39 \%$ & $33 \%$ & $12 \%$ & $9 \%$ & $6 \%$ & $.3 \%$ \\
\hline $\begin{array}{l}\text { I would rather do my research at the library than } \\
\text { online. }\end{array}$ & $8 \%$ & $10 \%$ & $31 \%$ & $30 \%$ & $20 \%$ & $.5 \%$ \\
\hline I regularly use the computer labs on campus. & $34 \%$ & $27 \%$ & $16 \%$ & $12 \%$ & $9 \%$ & $1 \%$ \\
\hline My career plans involve the use of computers. & $25 \%$ & $29 \%$ & $27 \%$ & $9 \%$ & $7 \%$ & $4 \%$ \\
\hline
\end{tabular}

A number of crosstabulations were run in-order to determine correlations among data sets. The first crosstabulation looked at responses by gender to the statement I am comfortable locating quality research materials such as books and journal articles in the library (See Table 2). A ChiSquare Test was run to obtain a measure of statistical significance with the significance level set at $a=0.05$. The Chi-Square Test indicated that $\mathrm{p}>.05(\mathrm{p}=.522)$ and cannot be regarded as significant (see Table 3 ). There is not sufficient evidence to assert that there is a relationship between gender and students' reported comfort levels in locating research materials and journal articles in the library. 
Table 2: Gender Cross Tabulation

\begin{tabular}{|c|c|c|c|c|c|c|c|c|}
\hline & \multicolumn{6}{|c|}{$\begin{array}{l}\text { I am comfortable locating quality research materials such as books and } \\
\text { journal articles in the library. }\end{array}$} & \multirow[t]{2}{*}{ Total } \\
\hline & & $\begin{array}{c}1 \\
\text { SD }\end{array}$ & $\begin{array}{l}2 \\
\mathrm{D}\end{array}$ & $\begin{array}{c}3 \\
\mathrm{~N} / \mathrm{U}\end{array}$ & $\begin{array}{l}4 \\
\mathrm{~A}\end{array}$ & $\begin{array}{c}5 \\
\text { SA }\end{array}$ & $\begin{array}{c}6 \\
\text { NA }\end{array}$ & \\
\hline \multirow[t]{2}{*}{ gender } & Male & 10 & 21 & 54 & 70 & 50 & 1 & 206 \\
\hline & Female & 19 & 53 & 82 & 146 & 108 & 7 & 415 \\
\hline Total & & 29 & 74 & 136 & 216 & 158 & 8 & 621 \\
\hline
\end{tabular}

$5=$ strongly agree; $4=$ agree; $3=$ neutral/undecided; $2=$ disagree; $1=$ strongly disagree; and $N A=n o t$ applicable.

Table 3: Chi-Square Tests

\begin{tabular}{|l|r|r|r|}
\hline & \multicolumn{1}{|c|}{ Value } & Df & $\begin{array}{c}\text { Asymp. Sig. } \\
\text { (2-sided) }\end{array}$ \\
\hline Pearson Chi-Square & $5.174(\mathrm{a})$ & 5 & .395 \\
Likelihood Ratio & 5.400 & 5 & .369 \\
Linear-by-Linear As- & .411 & 1 & .522 \\
sociation & 621 & & \\
N of Valid Cases & &
\end{tabular}

a 1 cells $(8.3 \%)$ have expected count less than 5 . The minimum expected count is 2.65 .

The second cross tabulation correlated computer ownership by the question I search journals and databases online (see Tables 4 and 5 ) and found the results to be statistically significant $\mathrm{p}<.05$ (.018), thereby the results of the analysis support the claim that there is a difference between computer owners and non owners when searching journals and research databases online. Students who own a computer were found to be significantly more likely to search journals and research databases online then students who do not own a computer.

Table 4: Computer Ownership Cross Tabulation

\begin{tabular}{|c|c|c|c|c|c|c|c|c|}
\hline & \multicolumn{6}{|c|}{ I search journals and research databases online. } & \multirow[b]{2}{*}{ Total } \\
\hline & & 1 & 2 & 3 & 4 & 5 & 6 & \\
\hline \multirow{2}{*}{$\begin{array}{l}\text { Own } \\
\text { computer }\end{array}$} & Yes & 36 & 77 & 117 & 171 & 132 & 9 & 543 \\
\hline & No & 24 & 27 & 46 & 60 & 29 & 7 & 193 \\
\hline Total & & 60 & 104 & 163 & 231 & 161 & 16 & 736 \\
\hline
\end{tabular}

$5=$ strongly agree; $4=$ agree; $3=$ neutral/undecided; $2=$ disagree; $1=$ strongly disagree; and $N A=$ not applicable. 
Table 5: Chi-Square Tests

\begin{tabular}{|l|r|r|r|}
\hline & \multicolumn{1}{|c|}{ Value } & Df & $\begin{array}{c}\text { Asymp. Sig. } \\
\text { (2-sided) }\end{array}$ \\
\hline Pearson Chi-Square & $14.740(\mathrm{a})$ & 6 & .022 \\
Likelihood Ratio & 14.693 & 6 & .023 \\
$\begin{array}{l}\text { Linear-by-Linear As- } \\
\text { sociation }\end{array}$ & 5.632 & 1 & .018 \\
N of Valid Cases & 736 & & \\
\hline
\end{tabular}

a 3 cells $(21.4 \%)$ have expected count less than 5 . The minimum expected count is .26 .

A one-way ANOVA was performed in order to compare means of multiple variables. The students level of computer proficiency which they reported as either being expert, intermediate, or beginning were examined against Likert-Scale questions 14-19 which examined library usage and conformability as well as the participants use of the internet to conduct searches for papers and projects (see Table 6). Questions 15, 16, 17 were found to be statistically significant with $\mathrm{p}<.05$ indicating that there is a difference between computer proficiency and each question. Questions $14,18,19$ were not found to be significant ( $\mathrm{p}>.05)$ indicating that there is not evidence to assert that there is a relationship between computer proficiency and each of the questions.

Table 6: ANOVA

\begin{tabular}{|c|c|c|c|c|c|c|}
\hline & & $\begin{array}{l}\text { Sum of } \\
\text { Squares }\end{array}$ & Df & $\begin{array}{l}\text { Mean } \\
\text { Square }\end{array}$ & $\mathrm{F}$ & Sig. \\
\hline \multirow{3}{*}{$\begin{array}{l}\text { (14) I am Comfortable } \\
\text { locating research materi- } \\
\text { als in the library. }\end{array}$} & Between Groups & 8.668 & 3 & 2.889 & 2.326 & .074 \\
\hline & Within Groups & 881.987 & 710 & 1.242 & & \\
\hline & Total & 890.655 & 713 & & & \\
\hline \multirow{3}{*}{$\begin{array}{l}\text { (15) I prefer to do my } \\
\text { research for papers and } \\
\text { projects online. }\end{array}$} & Between Groups & 31.706 & 3 & 10.569 & 8.092 & .000 \\
\hline & Within Groups & 933.824 & 715 & 1.306 & & \\
\hline & Total & 965.530 & 718 & & & \\
\hline \multirow{3}{*}{$\begin{array}{l}\text { (16) I know where to find } \\
\text { quality academic research } \\
\text { materials online. }\end{array}$} & Between Groups & 41.080 & 3 & 13.693 & 13.560 & .000 \\
\hline & Within Groups & 720.028 & 713 & 1.010 & & \\
\hline & Total & 761.107 & 716 & & & \\
\hline \multirow{3}{*}{$\begin{array}{l}\text { (17) I search journals and } \\
\text { research databases online. }\end{array}$} & Between Groups & 18.433 & 3 & 6.144 & 3.852 & .009 \\
\hline & Within Groups & 1129.477 & 708 & 1.595 & & \\
\hline & Total & 1147.910 & 711 & & & \\
\hline
\end{tabular}


(18) When conducting an online search, I am most likely to Google or Ask Jeeves.

(19) I would rather do my research at the library than online.

Between Groups
Within Groups
Total

Between Groups Within Groups

Total

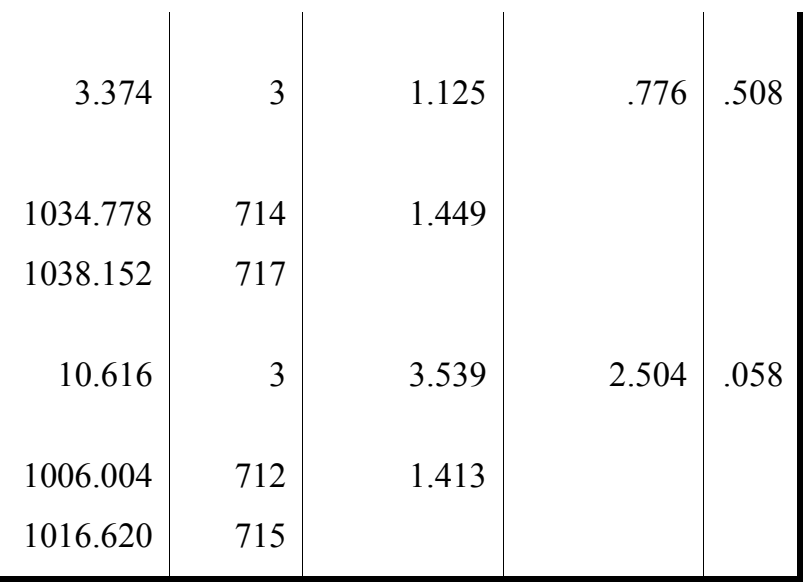

An additional one-way ANOVA was conducted to see if there was a correlation between completion of a college preparation program and rates of library usage, the locating of materials in the library, and the ability to search journals and databases online (see Table 7). The ANOVA revealed no statistically significant with a $\mathrm{P}$ value of $.404, .329$, and .112, respectively. There was not sufficient evidence to assert that there is a relationship between a students participation in a pre-college program and how regularly they visit the library, how comfortable they are in locating quality research materials or whether or not they search journals and research databases online.

Table 7: ANOVA

\begin{tabular}{|c|c|c|c|c|c|c|}
\hline & & $\begin{array}{l}\text { Sum of } \\
\text { Squares }\end{array}$ & $\mathrm{df}$ & $\begin{array}{l}\text { Mean } \\
\text { Square }\end{array}$ & $\mathrm{F}$ & Sig. \\
\hline \multirow[t]{3}{*}{$\begin{array}{l}\text { 12. I regularly visit the } \\
\text { library. }\end{array}$} & $\begin{array}{l}\text { Between } \\
\text { Groups }\end{array}$ & 1.230 & 1 & 1.230 & .697 & .404 \\
\hline & Within Groups & 1111.313 & 630 & 1.764 & & \\
\hline & Total & 1112.543 & 631 & & & \\
\hline \multirow{3}{*}{$\begin{array}{l}\text { 14. I am comfortable lo- } \\
\text { cating quality research } \\
\text { materials such as books } \\
\text { and journal articles in the } \\
\text { library. }\end{array}$} & $\begin{array}{l}\text { Between } \\
\text { Groups }\end{array}$ & 1.273 & 1 & 1.273 & .953 & .329 \\
\hline & Within Groups & 841.928 & 630 & 1.336 & & \\
\hline & Total & 843.201 & 631 & & & \\
\hline \multirow[t]{3}{*}{$\begin{array}{l}\text { 17. I search journals and } \\
\text { research databases online. }\end{array}$} & $\begin{array}{l}\text { Between } \\
\text { Groups }\end{array}$ & 4.088 & 1 & 4.088 & 2.537 & .112 \\
\hline & Within Groups & 1010.128 & 627 & 1.611 & & \\
\hline & Total & 1014.216 & 628 & & & \\
\hline
\end{tabular}

\section{Contributions}

This study provides research on a population that is expanding in numbers in higher education and that many educators, and much research, reports as being under-prepared for academic success (Allen, 1987; Hull, 2005; Morgan \& VanLegen, 2005; Pearson \& Young, 2002; Sax, Ceja, \& Teranishi, 2001). This paper builds on the findings of a number of similar studies that have been conducted at majority institutions and a handful of less detailed studies that were reported out of 
HBCU's a number of years earlier. The results of this study have encouraged the authors to both replicate and expand the research.

Responses to this study have shown that technology access and ownership is less prevalent than what has been reported out of majority institutions, but more importantly, that HBCU freshmen are less prepared to use the internet and libraries for scholarly pursuits.

\section{Limitations of This Study}

There are three significant limitations to this study and one minor limitation. The first limitation is the disproportionate number of respondents between the two institutions whereas at there were three times the number of respondents from Fayetteville State University as the University of Maryland Eastern Shore. Additionally, the UMES population was comprised exclusively of freshmen business majors with a $97 \%$ response rate while at FSU all freshmen were surveyed with a $91 \%$ response rate. On the other hand, a series of non-parametric tests were conducted to examine similarities and differences between response pools and the results showed that with confidence the opinions of both groups were consistent.

The second limitation of this study is that it focused solely on freshmen students attending Historically Black Universities. At the same time, this limitation results in data conducted on a population that is traditionally missing from the literature as the critical mass of African American college students can be found at HBCUs (Brown, 2004). It is important to note that HBCUs confer a statistically significant percentage of the bachelor's degrees earned by African Americans whereas the 105 four year and two year public and private HBCUs, which is a small percentage of the number of colleges in the United States, graduate one-fourth of the total number of bachelor's degrees awarded in the U.S to African Americans. Additionally, while the number of African Americans at both HBCUs and TWIs continues to grow, African American students are not completing their degrees at TWIs at the same rate as those attending HBCUs (Brown, 2004).

A secondary issue that arises when conducting studies at HBCUs is that with their low enrollment of non-blacks, as witnessed with the racial distribution of the population of this study, comparisons between racial groups cannot be made with validity.

The third limitation of this study is that the survey was not distributed at a majority institution which would have enabled comparative analysis across institutional type as well as by race an issue that is currently being addressed through an expansion of this study.

As a final and more minor limitation, participating students were not asked whether they have used search engines that are more scholarly in nature such as Google Scholar which has been remedied in the next generation of this study.

\section{Summary and Future Research}

This study examined the perceptions and experiences of freshmen students at two Historically Black Universities with respect to their technology ownership and usage and their information acquisition habits. The findings showed that most of the students owned a computer (74\%), had internet access at home (86\%), and went online daily (83\%) mostly using the internet for email and schoolwork). Few students were found to be frequent library users $(28 \%)$ although a majority of the respondents said that they use the library to conduct research for papers and projects $(75 \%)$ and $60 \%$ the participants said they were comfortable using the library for research purposes. The majority of the respondents said that they prefer to do scholarly research online (77\%) and knew where to find quality academic resources $(70 \%)$; however, the majority of students said that they are most likely to use a common search engine like Google or Ask to conduct their research for papers and projects (73\%). Additionally, students who own a computer were found to be signifi- 
cantly more likely to search journals and research databases online then students who responded that they did not own a computer.

Future research is needed in this area and these findings have helped to inspire a large-scale more in-depth research study. Additional questions have been added to the instrument and the survey is being replicated at one of the participating institutions and is also being implemented at a majority. This will result in the collection of a broader array of data that will enable greater comparative analysis.

Research in this area is important because the impact of technology has created a world in which its citizens should strive to achieve competency in the use of technological resources in the acquisition of knowledge to serve multiple objectives. This assertion is supported by the volumes of research that suggests that individuals need technological and information literacy in order to be informed and productive members of society.

\section{References}

Allen, W. (1987). Black college vs. white college: The fork in the road for black students. Change, 19, 2834.

American Library Association. (2006). Information literacy competency standards for higher education. Retrieved 7/25/06 from http://www.ala.org/acrl/ilcomstan.html

Breivik. P. (2000). Foreword. In C. Bruce \& P. Candy (Eds.), Information literacy around the world. Charles Sturt University.

Brem, S. K., \& Boyes, A. J. (2001). Using critical thinking to conduct effective searches of online resources. ERIC Clearinghouse on Assessment and Evaluation, College Park, MD. (ERIC Identifier: ED447199)

Brown, M. C. (2004). African-American student achievement in historically black colleges and universities. Diversity Digest, 8(1) 6-7

Bruce, C. (2003). Seven faces of information literacy. Retrieved 6/12/06 from: http://crm.hct.ac.ae/events/archive/2003/speakers/bruce.pdf

Buzzetto-More, N., \& Sweat-Guy, R. (2006, October). Technology backgrounds of freshmen students at historical black universities. Proceedings of the Global Digital Business Association. Las Vegas, NV.

Buzzetto-More, N. (2006, October). Using electronic portfolios to build information literacy. Proceedings of the Global Digital Business Association. Las Vegas, NV.

Caruso, J., \& Kvavik, R. (2005). Students and Information technology, 2005: Convenience, connection, control and learning. Educause Center for Applied research. (www.educause.edu/ecarl)

Darling Hammond, L. (1994). Linda Darling Hammond on the purpose for education. Retrieved 6/12/06 from http://www.ed.psu.edu/insys/esd/darling/purpose.html

Flowers, L. (2002). The impact of college racial composition on African American students' academic and social gains: Additional evidence. Journal of College student development. 43(3) 403-410

Hull, B. (2005, March). I don't see the point. Adult Learning, 29-30.

International Technology Education Association. (2003). Advancing excellence in technological literacy: Student assessment, professional development, and program standards. Reston, VA: Author.

International Society for Technology in Education. (2000). National Education Technology Standards. Retrieved 6/24/06 from http://cnets.iste.org/

Jackson, L., Ervin, K., Gardner, P., \& Schmitt, N. (2001). The racial digital divide: Motivational, affective, and cognitive correlates of Internet use. Journal of Applied Social Psychology, 31(10), 2019-2046 
Laird, T., Bridges, B., Homes, M., Morelon, C., \& Williams, J. (2004). African American and Hispanic student engagement at minority serving and predominantly white institutions. Paper presented at the annual meeting of the Association for the Study of Higher Education. November 4-7, 2004. Kansas City, MO.

Morgan, J. \& VanLengen, C. (2005). The digital divide and K-12 student computer usage. Issues in Informing Science and Information Technology, 2, 705-724. Available at http://2005papers.iisit.org/I56f86Morg.pdf

National Center for Education Statistics. (2003). Internet access in U.S. public schools and classrooms: 1994-2002. Retrieved June 29, 2005 from the National Center for Education Statistics Web Site: http://nces.ed.gov/pubs2004/2004022.pdf

No Child Left Behind Act of 2001, Part D, Sec. 2402. (2001). Retrieved 5/17/06 from http://www.nochildleftbehind.gov

North Central Regional Educational Laboratory. (2006). $21^{\text {st }}$ Century Skills. Retrieved 7/17/06 from http://www.ncrel.org/engauge/skills/techlit.htm

Outcalt, C. \& Skewes-Cox, T. (2002). Involvement, interaction, and satisfaction: The human environment at HBCUS. The Review of Higher Education, 25(5), 331-347

Pearson, G. \& Young A.T. (Ed.). (2002). Technically speaking: Why all Americans need to know more about technology. Washington, D.C.: National Academy Press. Available at from http://www.nae.edu/nae/techlithome.nsf

Sax, L., Ceja, M., \& Teranishi, R. (2001). Technological preparedness among entering freshmen: The role of race, class, and gender. Journal of Educational Computing Research, 24(4). 363-383.

Smith, I. (1999). Some myths about public library use. Impact. January.

Stern, C. (2002) Information literacy unplugged: Teaching information literacy without technology. White paper prepared for UNESCO, the US NCLIS and National Forum for Information Literacy. http://www.nclis.gov/libinter/

United States Department of Commerce. (2002). A nation online: How Americans are expanding their use of the internet. U.S. Department of Commerce, Economics and Statistics Administration, National Telecommunications and Information Administration. Washington, D.C.

Weil, T. (2006). Using technology to develop an information literate student. Proceedings of the UMES Office of Instructional Technology 2006 E-learning Seminar. Princess Anne, MD 


\section{Biographies}

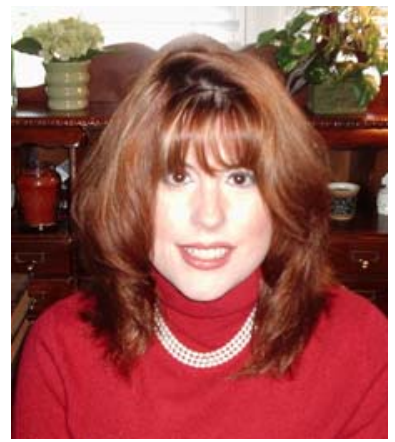

Dr. Nicole A. Buzzetto-More is an Assistant Professor, Business Education program coordinator, and Assurance of Learning coordinator in the Department of Business, Management, and Accounting at the University of Maryland Eastern Shore. She is also Co-Founder of the UMES Office of Instructional Technology. She received doctorate and masters degrees in communication and instructional technology from Columbia University and also holds degrees from the College of New Rochelle and Marist College. As a recognized assessment and elearning expert, she is a frequent presenter at conferences across the globe. She is on the editorial board of several journals, has authored numerous publications in referred journals, and has been recognized with an award from the American Distance Education Consortium. Her two books published in early 2007, Principles of Effective Online Teaching and Advanced Principles of Effective E-Learning, are available through the Informing Science Press. She is currently working on her third book.

Dr. Retta Sweat-Guy has an Ed.D. in Curriculum and Instruction with emphasis in Instructional Systems Design from the University of Kentucky. She received her masters in Public Administration from Kentucky State University and a Bachelor of Arts degree in Business Education from the University of Kentucky. Currently, she is Assistant Professor in the Department of Marketing and Business Education at Fayetteville State University in Fayetteville, North Carolina. Online teaching and learning serves as the basis for her current research for which she has presented at conferences and referred publications. She has and continues to conduct workshops and training sessions on the uses of web-based course management tools. She has published several book chapters and is currently working on her first fully authored book. 